\title{
Interpretation of Article One of the Convention against Torture in Light of the Practice and Jurisprudence of International Bodies
}

\author{
Kidus Meskele ${ }^{1}$ \\ School of Law, Wolaita Sodo University, Wolaita Sodo, Ethiopia \\ Email: kidumeskele@gmail.com
}

Received 6 December 2013; revised 3 January 2014; accepted 1 February 2014

Copyright (C) 2014 by author and Scientific Research Publishing Inc.

This work is licensed under the Creative Commons Attribution International License (CC BY). http://creativecommons.org/licenses/by/4.0/

\section{(c) (i) Open Access}

\begin{abstract}
Torture is one of the most brutal and horrendous human right violation, constituting direct attack on the core of human dignity. Though a number of international legal frameworks incorporate the right against torture, it is the convention against torture which provides the most prominent definition of torture. So this paper dedicated to explore the definition of torture in light of the practices and jurisprudence of the international bodies. Accordingly, there are four essential elements of the definition torture, which play a significant role in qualifying an "act" or "conduct" as torture. Apart from this, the paper has critically assessed the state obligation that flows from the definition provision. It has also discussed that the definition of torture is in continual process of evolution. In general, it is made clear that article one plays a pivotal in understanding the whole notion of the concept of torture, and implicating the state obligation with regard to torture.
\end{abstract}

\section{Keywords}

Torture; Convention; Human Right; International Body

\section{Section One}

\section{Overview of Torture: An Introduction}

Torture is an abominable act, a disregard and disrespect to dignity of human person and a serious violation of

${ }^{1}$ LL.M in Human Rights Law, Lecturer and Researcher in Wolaita Sodo University (WSU). 
one's human right. It is strictly prohibited by international laws. Despite being stringently outlawed torture continues to be practiced by most countries throughout the world. When he was a special Rapporteur on torture, Prof. Kojjmas has said that "torture is the plague of the second half of twentieth century. It is possible to eradicate plague with the help of advanced medical care but the evil of torture cannot be done away with by improved legal standard, hence, much more is needed to make the struggle against torture fruitful (UNGA, 2009).” That is why the struggle against torture has become one of the leading themes within international community.

The right to be free from torture is an absolute right that a state cannot avoid or limit it even in the time of exigency. The prohibition on torture is a preemptory norm of international law or jus congens. A number of international as well as regional human right treaties have incorporated the right to be free from torture. However it is the Convention against Torture, which is exclusively devoted to deal with the right against torture. The convention intended to commit every state to condemn acts which qualify as torture. Accordingly it provides the definition of the term torture and the state obligation that arises in relation with the commitment they pledged to be bound (Kelly, 2009).

Despite the definitional provision submitted by the convention the question as to whether under international law there is the coherent notion of torture is remained to be debatable (Wendland, 2002). These can certainly be conceivable from the different understanding of the notion of torture under international human right on one hand and in international criminal law on the other (Krause \& Scheinin, 2009).

However, as it is readily apparent from the practice of international bodies which increasingly borrow from one another's jurisprudence, a more consistent and coherent understanding of torture is put in place (Torture in International Law: A Guide to Jurisprudence, 2008). Furthermore as the culture of human right is more developed, the understanding of the term "torture" has come to cover acts which may not have been envisaged by the drafter of the convention. Thus an act which is previously falling short of being torture is now qualified as torture. And this has to be welcomed; once the ICRC commentary mentioned that strict interpretation of the definition would have no help in providing effective protection to the victim of torture than serving as a mere test for endless brutality of the torturers ${ }^{2}$. This reiterates that critical analysis of the essential elements which makeup the definition of torture is indispensable step in dealing with issues arise under the wider range of the right against torture.

\section{Section Two}

\subsection{Definition of Torture under UNCAT}

Various international and regional human rights instrument provides the right to be free from torture ${ }^{3}$. In fact most of them failed to provide any definition to the term "torture". The United Nation Convention against Torture (herein forth referred as to UNCAT) appeared to be the first instrument which has taken a remarkable step in providing the definition of the term torture (Burgers \& Danelius, 1998). Accordingly Article 1 of the convention states:

"For the purpose of this convention the term torture means any act by which sever pain or suffering, weather physical or mental, is intentionally inflicted on person for such purpose as obtaining from him or a third person information or a confession, punishing him for an act he or third person has committed or is suspected of having committed or intimidating or coercing him or a third person or for any reason based on discrimination of any kind when such pain or suffering is inflicted by or at the instigation of or with the consent or acquiescence of a public officials or other person acting in an official capacity. It does not include pain or suffering arising only from, inherent or incidental to lawful sanctions”.

But this definition is neither full-bodied nor acceptable in other sphere of international law (Roldely, 2002). In one instance the International Criminal Tribunal for former Yugoslavia (hereinafter "ICTY") held that the definition of torture in article one of UNCAT cannot be regarded as binding in every context since it is not definition of torture under international customary law ${ }^{4}$. However the broad convergence of the international instrument and international jurisprudence suggests the general acceptance of the main elements contained in the definition set out under article 1 of CAT.

\footnotetext{
${ }^{2}$ Ibid.

${ }^{3}$ UDHR, Art 4, ICCPR Art 7, ECHR, Art 3, IACHR Art 5, ACHPR, Art 5.

${ }^{4}$ supra note 2, pp 24.
} 


\subsection{The Essential Elements of the Definition}

Though the application and acceptance of the definition of torture in other international law is remained to be debatable but most international disposition and bodies tend to agree in four constitutive element of torture which are also explained as "element of the definition"5. Accordingly the four element of definition are; the nature of the act, the intention of the perpetrator, the purpose and the involvement of public official. The former UN Special Rapporteur on torture, Manfred Nowak, has also mentioned that these four elements contribute to comprehensive concept of torture, as distinguished from other form of ill-treatments ${ }^{6}$.

\subsubsection{The Nature of the Act}

While it is clear from the text of the provision that torture can result from "act", it is not similarly clear from article one weather omission can result in torture under the context of article one. However action by "omission” can inflict as much physical and mental harm as action by "commission". Hence the term "act” should not be interpreted narrowly. A number of international decisions and the work of human right monitoring body ${ }^{7}$ have referred to the notion of physical or mental pain or suffering, including pains or sufferings as result of omission, as violation of the prohibition against torture and ill-treatment. In one of the decision delivered by the European Commission of human rights, it is held that deprivation of food and other items constitutes act of torture ${ }^{8}$. Similarly in Ireland vs UK, one of the leading cases in the ECtHR jurisprudence, the court held that "deprivation of food and water" which infers an action by omission, constituted a breach of article 3 of the European convention on human right ${ }^{9}$.

Moreover the committee against torture has made it clear that a state party to the convention bears responsibility for acts and omissions of their officials; and others acting in the official capacity or on behalf of state ${ }^{10}$. It may be argued that states are not exonerated from its obligation to prevent torture which is the outcome of omission. Since there are many instance wherein, action by "omission” itself is enough to cause any harms which can qualify as act of torture under article one of the convention. If an "act" is to be understood as to exclude "omission", then it will be easy for the state party to evade obligation under the convention. Precisely this notion of interpretation will compromise the very reason of having the convention. Any interpretation of the texts of the treaty shall be in good faith and in light of its purpose and object ${ }^{11}$.

Here my point is any narrow interpretation of the term "act" offers state parties easy way-out to evade its obligation. And this is incompatible with the purpose and object of the convention. Hence act is not to be understood in any way as to exclude omission. This is also well established from the jurisprudence of the committee against torture $^{12}$. In one of its concluding observation the committee has reaffirmed that failure of the government to provide health care assistance was find out to be violation of the convention ${ }^{13}$. In any way states are under obligation to refrain from encouraging torture either through commission or omission. Thus the legal definition of torture encompasses both acts and omissions that inflict severe mental or physical pain or suffering.

The convention prohibits both physical and mental torture. HRC also has a view of considering intimidation and threats as mental torture which amounts to violation of article 7 of the covenant (ICCPR) ${ }^{14}$. Similar interpretation is deduced from the practice of $\mathrm{CAT}^{15}$.

\subsubsection{Intention}

Torture described as an act which is intentionally inflicted to the victim to cause physical or mental pain or ${ }^{5}$ Interpretation of torture in the light of the practice and jurisprudence of international bodies (2011), pp 2.

${ }^{6}$ Report of Special Rapporteur on Torture, Manfred Nowak, 5 February 2010 (A/HRC/13/39 Add.5), para. 30.

${ }^{7}$ The HRC has found violation of article 7 in number of cases which involves act of torture as result of omission. For instance, deprivation of food and water constitutes an act prohibited under article 7 in Muteba V Zaire (124/82), Kanana V Zaire (366/89).

8“"The Greek case”, Denmark vs Greek, communication No 3321/67, 3322/67, 5344/67, 1969 yearbook of the European convention on human rights, No 12, p 186.

${ }^{9}$ Ireland vs UK, communication No. 5310/71 ECtHR (series A), 18 January 1978.

${ }^{10}$ Committee against Torture, General Comment 2, Implementation of article 2 by state party, para 15.

${ }^{11}$ VCLT, Art 31 sub-article 1.

${ }^{12}$ For example Dmytro Slyusar V Ukraine (CAT 353/2008).

${ }^{13}$ The committee against torture concluding observation on Chile UN Doc. CAT/C/CR/32/5.

${ }^{14}$ See Quinteros V Uruguay (107/81). See also Schedko V Belarus (886/99), the committee considered that the factual situations have the effect of intimidating or punishing the families by intentionally leaving them under the state of uncertainty and mental distress.

${ }^{15}$ Dzemajl et al. V Yugoslavia, (CAT 161/00), where the majority of members of the committee found that the deliberate burning and destruction of Roma settlements, which conducted with a racist motive constituted cruel, inhuman or degrading treatment while the dissenting opinion of the minority found that demolition of the property and an intended racist attack has the effect of severe mental suffering which constituted act of torture. 
suffering. The "intentional" element is one of the main components which make up the international concept of torture $^{16}$. CAT has also emphasized that the element of "intent" in article 1 is essential thus the state party has to observe this element while farming the definition of torture in their domestic laws ${ }^{17}$.

Here the question is whether negligent infliction of pain and suffering may constitute torture. For instance a detainee who is forgotten, suffers from severe pain due to lack of food is without doubt is a victim of serious human right violation. However this treatment does not amount to torture since it lacks the requirement of "intent”. Many authors concluded that negligence is not sufficient to qualify an act as torture, whereas recklessness might suffice ${ }^{18}$. Furthermore it is readily apparent from the practice of CAT that an issue weather negligent constitutes torture is almost non-existent with the exception of one instance. In 2007, in the discussion forum on the report of Denmark, the delegation of the committee were asked for explanation of the rationale behind excluding negligence since it was "a well-established subjective component of the criminal liability."19 It is my firm opinion that an act of negligence does not count to torture. Since achieving the given purpose ${ }^{20}$ is impossible without acting or omitting deliberately. This suggests that negligence will not suffice to substantiate protection against torture claim under article 1 of the UNCAT.

\subsubsection{The Purpose}

The purposive element is central to the notion of torture as understood from the practice of the international bodies. It also serves as distinguishing element of torture from other ill-treatments ${ }^{21}$. Similar approach is followed in the international criminal law where the element of "purpose" used to distinguish torture from other form of ill-treatments ${ }^{22}$. The trial chamber in the Delalic case has held that torture is distinguished from other offences of willfully causing great suffering or serious injury primarily on the base of purposive element ${ }^{23}$.

In order to be prohibited act under article 1 , the conduct must be inflicted for such purpose as: extraction of confession; obtaining information from a victim or third person; punishment, intimidation and coercion; and discrimination. The legislative history of the convention infers that the list of purpose is meant to be illustrative than exhaustive ${ }^{24}$. The phrasing “...for such purpose as...” leaves an open interpretation for reason leading to infliction of torture. Perhaps one may argue that any other reason may be lead to infliction of torture. For instance the HRC in one of its concluding observation has pointed out that torture may be inflicted for any reason which is not related with the act of the state ${ }^{25}$. But this seems in paradox to the notion of torture under UNCAT. Though the term ("such purpose as....") is not exclusive, but as it is mentioned by many authors, it invites only those purpose which are similar with the purposes expressly listed ${ }^{26}$. This argument holds water given the fact that the term "such purpose as" is quite different from the term "any other purpose" under the Inter-American convention on torture ${ }^{27}$. The definition of torture on the latter instrument goes further and more expansive ${ }^{28}$ than UNCAT in that it does not require "severity" of pain and make reference to "any other purpose" rather than "such purpose as". According to the rule of interpretation the latter phrase purports for more narrow interpretation than the former. "Such purpose as...." proviso infers only similar purpose with the one expressly provided. Hence I assert that the element joining the list of purpose is best understood to be as "some connection with interest and polices of state or its organ.,29

This can also be inferred from the practice of the international human right monitoring body. Most often, the HRC has considers the conduct as torture when the pain inflicted for political reasons such as participation in political activity of the opponent party, supporting the opponent party, or being opponent to the ruling party ${ }^{30}$.

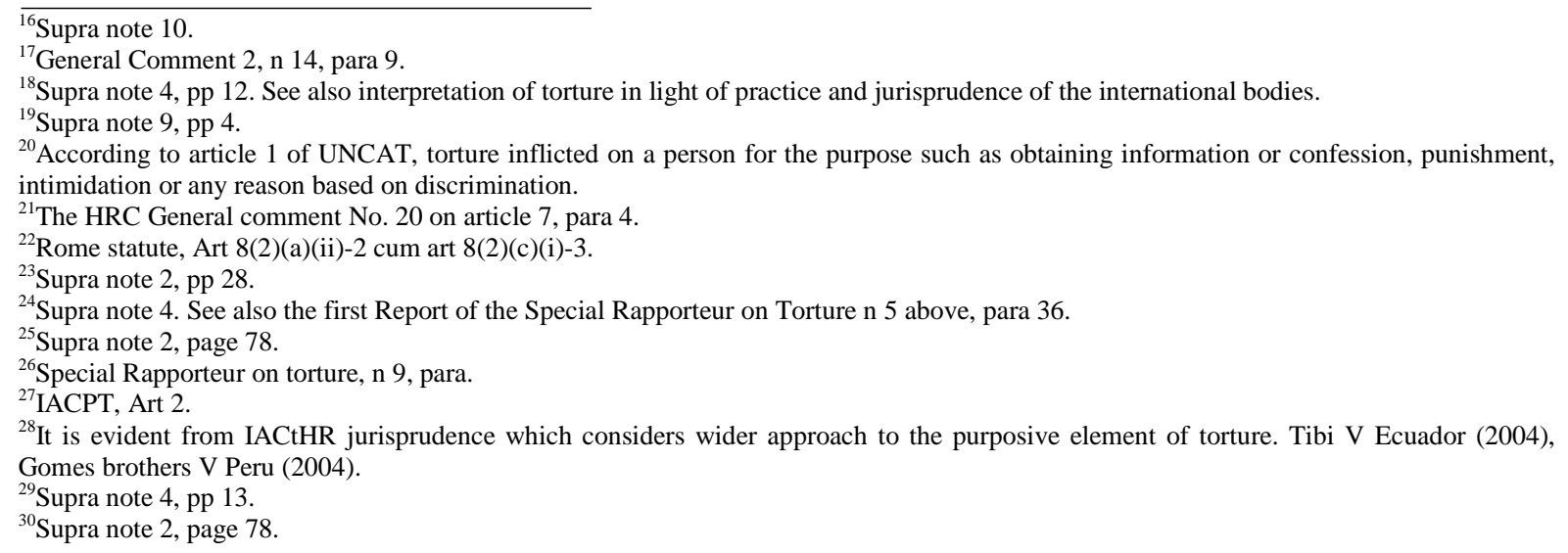


Similar approach can be safely inferred from the practice of CAT. There is no single instance where the committee ruled on violation of article 1 for any reason than in relation to state. This may also attribute to the fact that an act qualify as torture if it is state sponsored violation. In this regard it is worth noting, whenever torture occurs, it almost invariably takes place in political context. It is also a well-founded fact that torture takes place behind the closed door against powerless victim by the perpetrators which enjoy superiority to intimidate, punish or any similar reasons. That is why the UNCAT primarily concerned with preventing the most heinous act of treatment which is committed by the agent of state. Hence the term "such purpose as...", in any way purports for similar "purpose" linked with work of state agents.

\subsubsection{The Involvement of Public Officials}

1) Who are public officials?

The UNCAT specifies that an act qualify as torture if the pain or suffering inflicted by instigation, with the consent or acquiescence of the public officials or other person acting in official capacity. Despite the lengthy discussion, the working group drafting the convention is refrained from providing the definition of "public officials" ${ }^{\text {31 }}$. During the deliberation stage, some states have proposed for broader understanding of the term public officials $^{32}$. However none of the proposal is incorporated in the convention.

It is the jurisprudence of CAT which made clear that public official, in principle, refers to de jure government control whereas de facto control will be recognized in the absence of de jure control. In G.R.B vs Sweden the committee held that ill-treatment of the victim by the act of Sendeero Luminoso which is non-state entity controlling significant portion of Peru is not constituted an act of torture under article $1^{33}$.

However in Elmi vs Australia, the committee has noted that in the absence of central government in Somalia, "the warring factions operating in the state which have set up quasi-government institution and which exercise certain prerogatives which is comparable to those normally exercised by legitimate government" can fall within the phrase "public official or others persons acting in public official capacity ${ }^{34}$. But this does not have the implication that the committee deviated from its previous jurisprudences so as to consider de facto government control as authorities in the meaning of article 1.

This can be inferred from the committee's jurisprudence in H.M.H.I V Australia, where the committee reaffirmed that in presence of central government ( transitional national government of Somalia), an act of entities other than under the authority or tolerated by, new government did not fall within the definition of torture under article $1^{35}$. From this it can safely be deduced that the term public official refers to de jure government control.

2) State responsibility under UNCAT for act of torture

a) Instigation

The classical situation of state responsibility under article 1 arises when state agents directly or indirectly participate in the act of torture. This implies the moment where public officials involve either in incitement, inducement or solicitation of act of torture. This situation is well established under the international bodies' jurisprudence. In a number of cases which involve political interest of states, it is mentioned that states resorted to instigate torture against the opponent side. Torture under instigation of state is been the widespread practice, and continued to be the most common after the war on terror (Catarina \& Martin, 2009). The classical example in this regard is "torture Memos" suggested by USA, to interrogate suspects of terrorist act ${ }^{36}$.

b) Consent or acquiescence

The state responsibility under the convention goes beyond the traditional concept of responsibility and includes acts which are not directly inflicted by a public official but executed with their active or passive agreement or those occurred with their lack of intervention. This infers the notion of consent or acquiescence, which can give raise to state responsibility under article 1 of the convention.

${ }^{33}$ G.R.B V Sweden (CAT 83/97), the committee is of view that fear of persecution by the act of Sendeero Luminso is not attributable to public official under the meaning of article 1 . Since the latter has only de facto control which does not enjoy the support of Peruvian government. See also M.P.S V Australia (CAT 138/99).

${ }^{34} \mathrm{E}$ Imi vs Australia (CAT 120/98), the committee deviated from its jurisprudence in G.R.B Case. The major difference between the cases, in former case, people with de facto government control deemed as public official in the absence of de jure government control ( central government) while in latter case, entities with de facto control of government are not deemed as public official since public power is exercised by the de jure government.

${ }^{35}$ H.M.H.I vs Australia ( CAT 177/01).

${ }^{36}$ Ibid.
} 
The ECtHR has considered that a state was in breach of its obligation under article 3 of the European convention on human right because it failed to take sufficient measures in order to prevent some acts of torture administered by non-state actors ${ }^{37}$. The same court, in Opuz vs Turkey has found that the state was responsible for the act of torture inflicted by a husband on his wife, because the state had knowledge of impermissible act but failed to prevent, prosecute and punish the suspect ${ }^{38}$.

Similar approach was considered by the inter-American court in Velesquez-Roderguez V Honduras, where the court held that state was responsible for the act of private person through its failure of due-diligence to prevent the act of torture ${ }^{39}$. The decision of the courts confirm that state responsibility for the act of torture by consent or acquiesce is understood to be when state officials know or have reasonable ground to believe that act of torture is being committed by non-state actors or private actor but failed to prevent, prosecute or punish; or interfere in the impermissible act.

CAT has also elaborated the concept of consent or acquiescence by public officials in Dzemajl et al. vs Yugoslavia $^{40}$. In this case the police (public official) failed to take any appropriate measure to prevent the destruction of Roma settlement though they knew that the victims were facing risk. In its decision, the committee reiterated that the inaction of the police constituted "acquiescence" in the sense of article 16. The committee upholds the same position in many instances ${ }^{41}$. To conclude, state failure to take step to prevent torture by private individual, or to prosecute private individuals responsible for such acts, constitutes acquiescence in sense of article 1 .

The committee further clarified the notion of "consent" or "acquiescence" under its General Comment 2. It appears that consent or acquiescence is equated with failure of due diligence to prevent, investigate or punish acts of torture or ill-treatments committed by non-state actors or private actors ${ }^{42}$.

3) Is the act of private individuals will qualify as torture under Article 1 ?

The other important point worth to discuss is weather a conduct which is purely private nature will qualify as torture under article 1 of UNCAT. For instance if a man subjects his wife to pain or suffering which reach the threshold under article 1. In this regard it is better to refer to the definition provided under article 1 which is closely tied with the idea of torture being purposive official act. This is reflection of the problem which meant to be addressed by UNCAT, namely that of torture which involve the authority of the country and in respect of which the machinery of investigation and prosecution might therefore not function normally. It follows from the text of article 1 it does not apply to private act of cruelty: international concern arise where the cruelty has official sanction. Here the logic is crystal clear; torture is not applicable to individual cruelty, which is the concern of domestic criminal law than international standard. Hence purely private matter cannot fall under article 1 if it does not involve official sanction. These supposedly mean states are not generally responsible for acts beyond their control (cruelty which occur in private domain).

However they can be held responsible for acts of torture by private individuals if they fail to respond adequately to them, or fail to take any specific or general measure to prevent an act of torture. As I mentioned in the previous section of this paper state responsibility for acts of torture committed by private actors is established if there is consent or acquiescence of state. Thus torture inflicted by non-state perpetrators can be attributed to the state as violation of the convention if it is at list acquiesced by. This notion of understanding, nowadays, plays a pivotal role toward gender sensitive interpretation of torture.

But the questions still remained to be answered is if acquiescence by the state is required in order to find state responsibility for torture by private actor then when is it proved? Here the issue is whether states failure of due diligence to prevent the act at state level, where there is failure to put in place appropriate law and policies to address an act, is required to be proved; or state failure of due diligence at individual level, where the authority fail to take effective measure to protect a person known to be at risk, is required to be proved in order to establish state responsibility for acts of torture by acquiescence.

The ECtHR in Opuz vs Turkey ruled in favor of the victim based on the state failure of due diligence to

\footnotetext{
${ }^{37}$ A V UK (25599/94) rep-1996-vi judgment of 23 Sept 1998, the case involved step-father who prosecuted for caning his boy but acquitted by the jury that considered the punishment to be "reasonable chastisement". ECHR has found that the state was responsible for its failure to provide adequate protection to victim against ill-treatment. See also Z et al. V UK (2001).

${ }^{38}$ Opuz Vs Turkey (Application No. 33401/02), [2009] ECHR 879, 9 June 2009.

${ }^{39}$ Velesquez-Roderguez Vs Honduras (1982).

${ }^{40}$ supra n 19.

${ }^{41}$ CAT concluding observation on Slovakia (CAT A/56/44 (2001), Czech republic (CAT A/56/44 (2001) Georgia (CAT A/56/44).

${ }^{42}$ Supra n 14, para 18.
} 
prevent violence against women at state level which according to court, constitutes acquiesces ${ }^{43}$. While the IACtHR, in the Cotton field case, has held that the state could not be found responsible since there was no evidence that show the state agents did not know the murder and disappearance of women and girls in Cudad Juarez, Northern Mexico ${ }^{44}$. In this case the court is of a view that acquiescence of state to the act of private individuals could not be established since the state agent did not know that the complaints are running risk of torture.

From the committees jurisprudence it is clear that "acquiescence" by state agent which gives raise to state responsibility under article 1 will be established, when state authority knows or have reasonable believe that impermissible acts are committed by private individuals but failed to prevent, prosecute or punish the act ${ }^{45}$. This implies the latter approach, i.e. failure of due diligence at individual level is used to establish acquiescence of state agent. It is also equally clear that acquiescence of state agent can be asserted if there is failure of due diligence at state level, where there is failure to put appropriate law or polices in order to prevent torture. The Committee under in its General comment 2, has reiterated that state parties should adopt effective measures (mainly include legislative and policy) to prevent authorities from consenting or acquiescing any act of torture. From this it follow that state agent's acquiescence to acts of private individual can be established if a state failed to bring any legal or policy change which address the impermissible acts.

\section{Section Three}

\subsection{Acts Which Fall outside the Ambit of Torture}

\section{Justified Sanction}

Unlike Article 7 of the ICCPR, article 1 of the UNCAT describes an exception to prohibition on torture, where the definition of torture specifically excludes "pain or suffering arising only from, inherent in or incidental to lawful sanction". The "lawful sanction" clause was inserted on insistence of some Islamic state and USA delegate, and often used to justify corporal punishment and death penalty ${ }^{46}$. However neither the jurisprudence of the HRC nor CAT warranties this interpretation. While the declaration against torture has mentioned that lawful sanction to extent constituent with "standard minimum rule for the treatment of prisoners" is only welcomed, the UNCAT does not elaborate the concept of lawful sanction.

But I argue that this in any way does not license any act that may reach the threshold of impermissible act in sense of article 1. For one thing the absolute nature of the prohibition on torture and the need for consistency of application does not allow doing so. For stronger reason, in the international law principle, states cannot invoke their internal law as a justification for its failure to observe its international obligation ${ }^{47}$. Thus states are not allowed to enact any law which stands against the convention.

In view of the UN special Rapporteur on torture, "lawful sanction" exclusion necessarily refers to practice which is commonly accepted as legitimate by international community, such as deprivation liberty through imprisonment, which is almost common to all penal system ${ }^{48}$.

However procedurally correct sanction may still constitute acts fall under article 1 of UNCAT. For instance the administration of punishment as flogging, stoning or amputation cannot be lawful simply because the punishment is authorized through procedurally legitimate manner.

The practices of the human right monitoring bodies also evince that any legally authorized punishment does not automatically qualify as lawful sanction in the meaning of article 1. The HRC in Osburne V Jamaica has noted that the lawfulness of any sanction will be determined by reference to national and international law ${ }^{49}$. In one of the case ${ }^{50}$, the HRC held that mere deprivation of liberty that the complaint subjected does not constitute violation of article 7; rather it is embarrassment inherent in disciplinary measure. Moreover in number of cases involving death penalty, the HRC has found out violation of article 7 of ICCPR.

Similar approach can be inferred CAT practice. In Nikolov vs Bulgaria ${ }^{51}$, the committee is of view that pains

\footnotetext{
${ }^{43}$ Supra note no 43.

${ }^{44}$ IACtHR case Gonzalez et.al (“cotton field”) vs Mexico, 16 November 2009.

${ }^{45}$ Supra n 14, para 18. See also Besim Osmani vs Republic of Serbia (CAT 261/2005).

${ }^{46}$ Supra n 40, p. 156.

${ }^{47}$ Supra 15, Art 27.

${ }^{48}$ supra note 2, pp 29.

${ }^{49}$ Osburne vs Jamaica (759/97).

${ }^{50}$ Vuolanne vs Finland (265/87).

${ }^{51}$ Kostadin Nkiolov Keremdchiev vs Bulgaria (CAT 261/2005).
} 
or suffering incidental to lawful sanction is tolerable in so far it is proportional. In this case, the pain and suffering inflicted up on the victim by the police constituted act of torture. In A.S V Sweden ${ }^{52}$, the committee considered that "stoning to death" sanction imposed up on the complainant for the crime of adultery constituted torture under the meaning of article 1 . It is readily apparent that "lawful sanction" has to be interpreted restrictively in a manner compatible with purpose and object of the convention.

\section{Section Four}

\subsection{State Obligation Which Arise from Article 1 of the Convention}

International human right treaties provide individuals with range of guarantees related with rights. Each of these rights carries with it corresponding obligation by the state. The fundamental concept is that human right is the normative articulation of the fundamental rules which mediates the relationship of organ of the organized society- typically the state and the individual member of the society ${ }^{53}$. Similarly the convention against torture imposes significant obligation on states not on individual. In this regard the definitional provision of the convention has prominent role in implying state obligation under the instrument. The committee in para 9, of General comment 2, has pointed out that state parties are required to adhere to the definition of torture under article 1 for the purpose of defining the obligation of state.

Article 1 requires a state party to prevent any act of torture that might be committed through its agent's direct participation as well as act of torture by private individuals up on acquiescence. This clearly connotes that a state has positive as well as negative obligation. The negative obligation of a state is it should refrain from interfering in individual's right to be free from torture. Thus a state authority shall not instigate any act of torture. Whereas the positive obligation purports to its obligation to take all appropriate measures (includes but not limited duty to investigate, criminalize, punish act of torture or duty to redress) so as to protect everyone against torture. Logically thinking, the text of the definition provision implies to state obligations envisaged under the convention in relation with prohibition against torture.

In number of instance regarding allegation as to violation of article 2, 12, 13 or 14 , CAT used to trace back to article 1 of $\mathrm{UNCAT}^{54}$. More clearly in Saadia Ali vs Tunisia ${ }^{55}$, the committee reiterated that state obligations under article 2, 11, 12, 13 and 14 comes to scene in so far as the act to which the complainant was subjected is considered act of torture in the meaning of article 1 . The committee recalled the same jurisprudence in number of $\operatorname{cases}^{56}$. This decision confirms that state party's obligations under article1 implies to obligations enshrined under the following provisions of the convention.

The committee further addressed the issue of state obligation with regard to prohibition against torture in its General comment 2. Accordingly a state party has obligation to prevent the act of torture through taking measures provided under articles $2-15$ of the convention ${ }^{57}$. As per article 2, states are required to take effective legislative, administrative, judicial or other measure to prevent act of torture. This provision is mainly intended to provide authority to build up on the remaining articles and to expand the scope of measure required to prevent torture $^{58}$. So in this section the main obligations of states which are commonly raise in the case laws will be addressed.

\subsection{Duty to Enact and Enforce Legislations Criminalizing Torture}

The UNCAT, as per article 4, explicitly obliges state party to adopt legislation which criminalize act of torture, while a similar duty may be inferred in the ICCR. Article 4 provides that state party must ensure all form of torture (including attempted torture) is punishable offence under their domestic criminal law.

CAT experience suggests that as per this provision, states are not only required to criminalize act of torture in their domestic law but also to adopt the definition of torture that covers all elements contained in article 1 of the 
convention $^{59}$. The committee used to follow up if the definitions adopted by state are compatible with article 1 of the convention ${ }^{60}$. Here the rationale is to avoid any discrepancies between the conventions definition and the one incorporated in state criminal law which has the potential to create any impunity. Hence it would be violation of the convention if a state prosecutes an act solely as ill-treatment while it contains all elements of torture ${ }^{61}$. Apart from this the committee has expressed its concern about appropriate punishment for torture ${ }^{62}$.

However it does not specify a minimum penalty that reflects the gravity of the offence. But in one of the case, Kepa urdi vs Spain $^{63}$, the committee held that the state was in breach of article 4(2) because of imposing light penalty on three civil guards who had been found guilty of torture. In the same case, the committee found that the state violated article 2(1) by granting pardon which has the effect of allowing torture go unpunished and encourage its repetition. By similar reasoning, the committee reiterated that amnesties for crime of torture are incompatible with the state obligation under article 4(2). Though it would be rush to conclude based on a single case, but still possible to deduce that a state obligation under article 4 is not only about naming torture as crime but also providing appropriate punishment taking the gravity of the offence in to account. This further strengthens by the jurisprudence of the HRC regarding article 7 of the ICCPR. The HRC is of view that amnesties are in general incompatible with the state obligation regarding article 7.

\subsection{Duty to Investigate}

The UNCAT as well as the ICCPR envisages state parties duty to investigate allegation of torture. Duty to investigate under article 12 of UNCAT is complemented by article 13, which provide individuals the right to complain to competent authority. Article 13 aimed solely at having the fact established as quickly as possible by the competent body, hence, it constitutes the most important right for the victim of torture.

According to article 12, a state required to undertake prompt and impartial investigation. The committee is of view that the investigation must be effective and thorough. From the CAT's jurisprudence, effective investigation involves "promptness" 64 , impartiality of the investigator (qualified individual) ${ }^{65}$, investigation "capable of determining both the nature of the alleged act and the identity of the perpetrator"66, and the victim has to be informed the outcome of the investigation immediately ${ }^{67}$. Of course how prompt is prompt, is something which has to be seen case by case scenario. In Blanco Abad vs Spain ${ }^{68}$, the committee reiterated that "promptness" is essential requirement in protecting the victim from the alleged act of torture, and held the state responsible for violation of article 12 because the period of 18 day between the initial report of ill-treatment and initiation investigation is too long. While in Saadia vs Tunisia, delay of 23 month before the investigation is initiated, constituted violation of article 12. The HRC has also emphasized on the effectiveness of the investigation in Fuenzalida vs Ecuador ${ }^{69}$, where it found the investigation insufficient in specific circumstance of the case, hence the state is not in compliance with duty to investigate.

Furthermore the state obligation under article 12 does not depend on submission of formal complaint. Rather it is sufficient to have allegation of torture ${ }^{70}$, or that reasonable grounds exist to believe that torture may have occurred, whatever the source of suspicion ${ }^{71}$. All that may safely be inferred from this is that investigation in the sense of article 12 is the one which has to be effective enough to address the allegation of torture.

\subsection{Duty to Exclude the Statement Obtained through Torture}

Effective prevention of torture presupposes making any evidences obtained by torture inadmissible. This finds

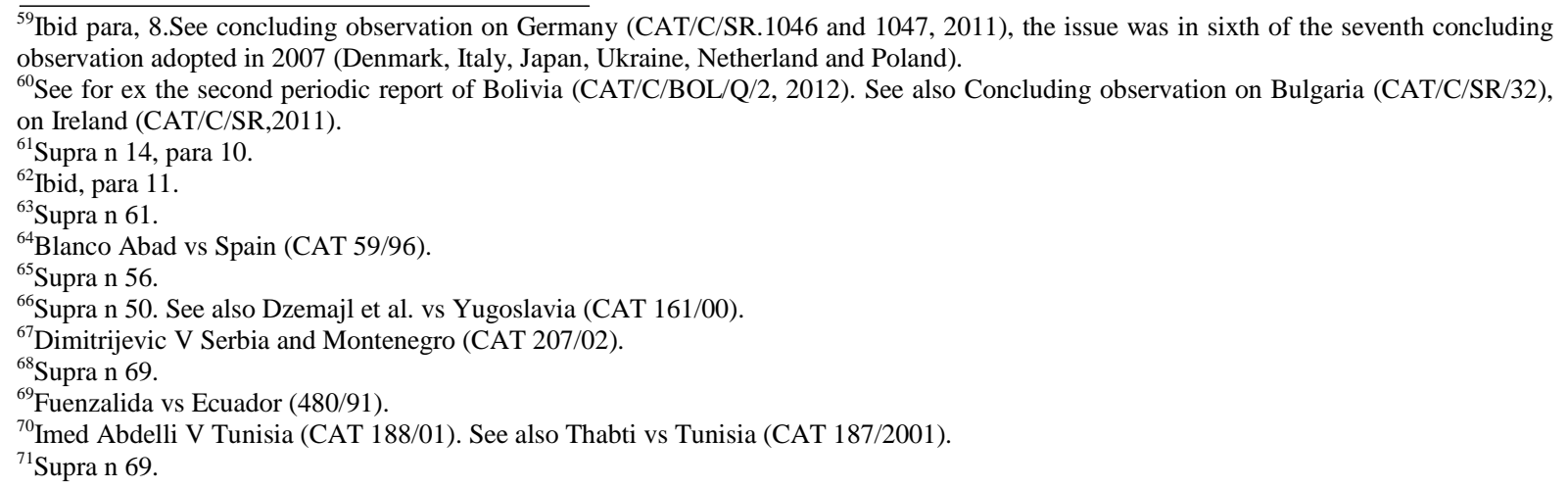


its strongest expression under article 15 of UNCAT which stipulates that state party shall "ensure that any statement which is established to have been made as a result of torture shall not be invoked as evidence in any proceeding." Similarly article 14 (3) g of the ICCPR stipulates that no one is compelled to testify against himself or to confess guilt. This implies that statement obtained by infliction of torture is inadmissible. The HRC reinforce this obligation and holds that " It is important for the discouragement of violations under article 7 that the law must prohibit the use of admissibility in judicial proceedings of statements or confessions obtained through torture or other prohibited treatment" ${ }^{, 2}$.

Regarding the protection under article 15, in P.E vs France ${ }^{73}$, CAT has held that any statement made by the victim about him or her as well as third party is prohibited. The prohibition also encompasses any derivative information or evidence of statement gained as result of torture. This seems logical, given that the vast majority of torture is inflicted in the course of criminal investigation with purpose of extracting information, the safeguard intend to remove prime incentive for torture. The committee is also view of that the corresponding obligation of the sate under the provision is to ascertain whether or not the statement is obtained by torture. Furthermore the state has to provide individuals with right to challenge the legality of any evidence plausibly suspected of having obtained as result of torture.

\subsection{Duty to Train Personnel and Provide Procedural Safeguard}

Most often, torture occurs when a person is deprived of liberty, weather in judicial or administrative context. Thus individuals who lost their liberty are particularly at high risk of being tortured. Procedural measures are one of the most basic safeguard nonetheless crucial measures to prevent torture in this context.

Both the UNCAT and ICCPR commits state party to take procedural measures so as to prevent act of torture. This basically refers to state obligation under article 10 and 11 of the UNCAT. According to article 10, a state party is required to give training regarding prohibition against torture to personnel that may contact with detainee in the custodial, prison or detention camps. But now this obligation is further expanded to include state obligation to prevent torture in all context of custody or control, for ex. hospitals and schools ${ }^{74}$.

Regarding the content of the training program, the training should specifically be on the provisions of the convention $^{75}$. It is recognized that the Istanbul protocol should be integral part of the training. States are also required to evaluate the effectiveness and impact of the training in reducing incidence of torture.

Apart from this, as per article 11, state parties are obligated to systematically review interrogation rules, instructions, methods and practices as well as arrangements for custody and treatment of person detained, arrested or imprisoned. The CAT considers that Article 11 requires compliance with international standards including the Standard Minimum Rules for the Treatment of Prisoners ${ }^{76}$ and the Body of Principles for the Protection of All Persons under any Form of Detention or Imprisonment ${ }^{77}$. This further reaffirmed in Barakat vs Tunisia ${ }^{78}$, where the committee found that the state was in breach of article 11 because of the death of detainee as result of torture.

\subsection{Duty to Grant Redress and Compensate Victim}

One of the most important rights of victims of torture is the right to be redressed. Both UNCAT and the ICCPR imposes obligation on state to grant redress and provide adequate compensation for the victims of torture (Joseph et al., 2004). As per article 14 of the UNCAT, state parties are required to ensure in its legal system that the victims right to obtain redress and have enforceable right to fair and adequate compensation. In its decision on Dzemajl et al. vs Yugoslavia, the CAT noted that the scope of application of this provision refers only to act of torture in the sense of article 1 . However in its recent General comment 3, it has considered that the provision is applicable to all types of torture and ill-treatments ${ }^{79}$.

Moreover the committee clarified that the term "redress" in article 14 encompasses the concept of effective

\footnotetext{
${ }^{72}$ Supra n 25, para 12.

${ }^{73}$ P.E Vs France (CAT 193/01).

${ }^{74}$ Supra 14, para 15.

${ }^{75}$ Concluding observation on Sweden (CAT/C/SWE/CO/5, 2008), on Ecuador (CAT/C/ECU/CO/4-6, 2010).

${ }^{76}$ See for ex Concluding observation on Kazakhstan (UN.DOCA/55/44, 1999).

${ }^{77}$ See for ex concluding observation on Monaco (CAT/C/CR/32, 2004).

${ }^{78}$ Barakat Vs Tunisia (CAT 60/96).

${ }^{79} \mathrm{CAT}$ General Comment 3, Implementation of article 14 by state parties, para 1.
} 
remedy and reparation ${ }^{80}$. The committee is of opinion that article 14 guarantees not only monetary compensation but also, restitution, rehabilitation, satisfaction and the guarantee of non-repetition ${ }^{81}$. This can also be traced form its case laws, like Ura Guridi vs Spain ${ }^{82}$, where the committee explained that the notion of compensation under article 14, should "cover all the damages suffered by the victim, which include among other measures, restitution, compensation, and rehabilitation of the victim, as well as measures to guarantee the non-repetition of the violations".

As per paragraph 5 of the General comment 3, the obligation of state parties to provide redress under article 14 are twofold: procedural and sustentative. The procedural obligation mainly related with obligation to put in place legislations which establish compliant mechanism, to have independent and competent investigation body and institution ${ }^{83}$. And the substantive obligation of the state requires a state party to ensure victims right to full and effective reparation ${ }^{84}$. In general, article 14 plays a pivotal role on prohibition against torture. Of course the right to redress comes to picture after the happening of the harm. But effective and comprehensive reparations have inherent preventive and deterrent effect in relation to future violation.

\section{Section Five}

\section{The Evolving Interpretation of Article One}

The traditional and the most famous understanding of torture is focused on the pains and suffering inflicted in the course of criminal investigation or in the context of custodial control. But nowadays as experiences of international human right bodies ${ }^{85}$ evince, this notion is being eroded. The international legal framework implementing the probation of torture (CAT) — once criticized for ignoring torture outside custodial context, is now being harnessed to recognize and validate the seriousness of this harm (Manfred, 2009). There is ongoing paradigm shift, which increasingly encompasses various forms of abuse outside the custodial context within the discourse on torture.

Historically, torture in non-custodial settings like various forms of violence against women (domestic violence, rape, honor-killing and female genital mutilation), torture in healthcare setting (denial of reproductive rights, abortion), or human trafficking were perceived to be private matters which involve infliction of harms by non-state agents, therefore cannot constitute torture in sense of article 1. However, recently, CAT is of a view that torture in non-custodial context may render state responsibility under article 1 if the acts are acquiesced by the state authority. This is also reaffirmed in its General comment 2, which submits that state party's can be held responsible for torture in non-custodial context, where its failure to intervene encourages, enhances the danger or privately inflicted harms.

In number of instances the committee suggested that state parties are in breach of the convention for failure to take actions in cases of gender-based violence's like, domestic violence ${ }^{86}$, female genital mutilation ${ }^{87}$ and rape. Moreover CAT considers that state parties denial of reproductive rights and abortion constitutes torture in sense of article $1^{88}$. It also expressed its deep concern regarding the prevalent practice of human trafficking ${ }^{89}$ and recommends state parties to take appropriate measure in order to prevent torture inflicted in course of trafficking.

In general, the language used under article 1 regarding consent or acquiescence by public officials clearly extends state obligation to prevent torture in non-custodial context. It is also revealed that others requirement of article 1 can be fulfilled in the case of torture in non-custodial context, since in most of those acts, the pain or suffering inflicted on the victim as much severe as pain or suffering inflicted in custodial context.

Furthermore, non-custodial tortures are manifestation of discriminatory views. Precisely, this satisfies purposive element of "discrimination". And the intent requirement can be effectively implied whenever there is a purpose to be attained. Therefore harms inflicted on victims in non-custodial context can constitute torture in the 
meaning of article 1 of the UNCAT. From this follows that state parties are under obligation to prevent, punish or redress acts of torture in non-custodial context.

Over time the human rights bodies and experts have increasingly recognized that people may be at risk of torture in the case of death penalty and corporal punishment, which a number of state have claimed fall under "the lawful sanction" exception. CAT is of view that the methods for carrying out the death penalty or the death row phenomena may amount to torture. It also expressed its concern that the lethal injection method of execution should be reviewed since it has a potential to cause pain or suffering that amount to torture ${ }^{90}$.

CAT has also noted that the circumstances surrounding the death penalty may render its imposition, violation of the convention. This mainly refers a fair trial issues. In general, CAT raised death penalty issue in number of discussions with state, welcomes its abolition in concluding observations and recommends its abolition, but at no point it explicitly stated that death penalty per se is incompatible with the UNCAT. This can also be inferred from the well-established jurisprudences of the HRC, which considers death penalty as well as detention in death row per se cannot render breach of article $7^{91}$. This in turn may lead one to argue that death penalty will still fall in "lawful sanction" clause, since what accounts to torture is not imposition of death penalty itself. Rather its method of execution and death row phenomena.

CAT has also expressed its deep concern regarding the corporal punishment. The committee is view of that state tolerance to corporal punishment will be in breach of the convention, and recommends its absolute prohibition in every setting (including punishment of children by their parent) ${ }^{92}$. The committee further recognized that "reasonable or moderate chastisement" in disciplining children fall within the impermissible act. Thus state parties are required to prohibit moderate chastisement as well. This is more strengthening by the CRC General comment 8 , which submits the absolute prohibition of corporal punishment in strongest tone. But I venture to suggest that the prohibition of reasonable or moderate chastisement will have a significant drawback from the perspective of child disciplining. I strongly argue that so far the treatment does not reach the minimum threshold of severity as required by article 1 or 16 of UNCAT, upholding corporal punishment is desirable.

From foregoing discussion, it is clear that the definition of torture is in process of continual evolution so as to encompass torture outside custodial setting. This has a pivotal role in protecting individuals from torture, since characterizing an act as "torture" has strong implication in term of state obligation to criminalize the act, bring the perpetrator to justice and redress the Vitim.

\section{Conclusion}

Though there are a number of legal frameworks which stipulate the right to be free from torture, it is the Convention against Torture that provides the most detailed right against torture. The convention is also the first legally binding instrument to provide prominent definition of torture. Accordingly, the definition of torture is made up of four essential elements: the nature of the act, intent, purpose and state involvement.

There are three major findings of this study. The first is that four elements are useful guide in order to characterize an act as one of torture or other ill-treatment. Secondly, the definitional provision is significant in defining the state obligation. Finally definition of torture under the convention is in process of continual change so as to encompass torture in non-custodial context. In general understanding, and critical analysis of article 1 is important in order to appreciate individuals' right against torture, and the extent of corresponding state obligation under the convention. It is also the writer's firm belief that this paper will contribute paramount importance in providing crystal clear understanding of the right against torture to the academia-students and staffs of legal studies, and non-governmental organizations working on projects against torture. Moreover the writers are convinced that the paper provides sufficient information on the international practices regarding the protection against torture, therefore, will offer a lot of help for those who are interested to conduct further study on the right against torture.

\section{References}

Burgers, J., \& Danelius, H. (1998). The United Nations Convention against Torture: A Handbook on the Convention against Torture and Other Cruel, Inhuman or Degrading Treatment or Punishment (pp. 10-12). Dordrecht: Nijhoff.

\footnotetext{
${ }^{90}$ Supra n 4, pp 35.

${ }^{91}$ Johnson v Jamaica (588/94).

${ }^{92}$ Concluding observation on Ireland(2011), Germany (2011).
} 
Catarina, K., \& Martin, S. (2009). International Protection of Human Rights: A Textbook (p. 677). Turku/Åbo: Åbo Akademi University, Institute for Human Rights.

Joseph, S., et al. (2004). International Covenant on Civil and Political Rights: Cases, Materials and Commentary (2nd ed.). Oxford: Oxford University Press.

Kelly, T. (2009). The UN Committee against Torture: Human Rights Monitoring and the Legal Recognition of Cruelty. Human Rights Quarterly, 31, 567-591. http://dx.doi.org/10.1353/hrq.0.0094

Krause, C., \& Scheinin, M. (2009). International Protection of Human Rights: A Textbook Institute for Human Rights, Abo Akadami University. Institute for Human Rights. www.utica.edu/academic/institutes/ihrec/publications/abopub.cfm

Manfred, N. (2009). Torture and Enforced Disappearance. In C. Krause, \& M. Scheinin (Eds.), International Protection of Human Rights: A Textbook (pp. 151-182). Turku/Åbo: Åbo Akademi University, Institute for Human Rights.

Roldely, N. (2002). The Definition of Torture under International Law. Oxford: Oxford University Press.

Torture in International Law: A Guide to Jurisprudence (2008).

United Nations General Assembly (UNGA) (2009). Report of the Committee against Torture (p. 392). New York: UNGA. (GAOR Sixty-fourth Session, Supplement No. 44 (A/64/44)) (also available in other official languages of the UN system).

Wendland, L. (2002). A Handbook on State Obligation under the UN Convention against Torture. Geneva: Association for the Prevention of Torture (APT). 